\title{
Totalitarianism and the 'Repressed' Utopia of the Present: moving beyond Hayek, Popper and Foucault
}

\author{
MARK OLSSEN \\ University of Surrey, Guildford, United Kingdom
}

\begin{abstract}
This article starts by reviewing the negative account of utopian thinking in dominant liberal western political theory, through the positing of a link between utopianism and totalitarianism, as present in the writings of liberal writers like Hayek, Popper, Berlin and others. As such, this article constitutes a critique of the liberal theories of utopianism and totalitarianism as well as positing alternative conceptions. It uses Michel Foucault's views to advance beyond the liberal mind-set in order to rehabilitate the concept of utopia as both a substantive and methodological conception for both democratic and educational theory, and argues for a revival of utopian thinking as necessary for extending and deepening democracy in the world post $9 / 11$.
\end{abstract}

A utopia, from one point of view, implies a distinction between things as they are and things as they should be. In this sense, a utopia implies an ideal society created by deliberate human endeavour. Such a definition typically includes a vision of an ideal existence for a collectivity. The utopias of the renaissance, for instance, described ideal imaginary societies characterised as if they operated in the present. They were fictional characterisations expressed so as to represent an ideal blueprint of how human groups could or should co-exist. As blueprints they combined both substantive and methodological concerns. That is, they spelt out the substance of how human society should be structured, and they constituted a method to enable comparison with actually existing societies. As often as not, because they were structured systemically, representing the individual in relation to complex institutional and social processes, they would address and resolve complex issues relating to structure and agency, freedom and determinism, morality and law, and social justice as well. The utopias of the Renaissance, for instance, represented a possible future, recapturing the authority and stability of the ancients. Most stressed stability at the expense of 
change, and repressed expressions of difference and diversity. Thomas More [1], writing in the early sixteenth century, for instance, imposed restrictions on travel, public gatherings, and the expression of political ideas, especially as influenced by the rise of the recently invented printing machines. More's conception of utopia, like those of von Gunzburg [2], Doni [3], Campanella [4], Andreae [5], Burton [6] and Bacon [7], emphasised social justice, the moral life, the relations of the individual to the polis and the absence of exploitation. Miriam Eliav-Feldon (1982, p. 85) characterises renaissance utopias as resting on four motives: social justice, a religiously moral life, the eradication of individualism, and simplicity.

It may be this renaissance characterisation of utopia, with its emphasis upon stability, consensus, and holistic construction, that accounts for the bad image of utopian thinking in Western political culture. Such a negative view is expressed by Ralph Dahrendorf (1967, p. 139), for instance:

One of the basic assumptions of all utopian constructions is that conditions may be created under which conflicts become superfluous. Indeed, the resulting state of harmony is the theoretical basis of the persistence of the social structure of utopia. But in reality these conditions do not exist. In fact, with the terrible dialectics of the non-rational, it happens that utopia first requires and then glorifies suppression.

What Frederich Hayek termed, as Erik Olin Wright (1995. p. x) reminds us, the 'fatal conceit' - 'the belief that through rational calculation and political will, society can be designed in ways that will significantly improve the human condition' (Wright, 1995, p. x) - symbolises the negative view of utopian theorising that has characterised liberal analyses. This type of anti-utopian thought, expressed forcefully in Hayek's The Road to Serfdom, was to be taken up by political philosophers like Karl Popper, in The Open Society and Its Enemies, and The Poverty of Historicism, and, in more recent times, such an anti-utopian conception has been echoed by Michel Foucault in an assortment of comments and interviews. In this short essay I want first to spell out the anti-utopian argument as represented by Hayek and Popper representing it as embodying a distinctively liberal viewpoint. I then want to consider Foucault's viewpoints on utopias in order to gain some insight into how the liberal objections can be overcome. Finally, I will argue that a utopia is best represented as embodying an ideal of social organisation that is not only representable in models of an ideal form of society in the future, but also always necessarily inheres in any present form of social organisation. That is, within actually existing societies, as depicted by liberals, there is I will argue a 'latent' or 'repressed' utopian ideal.

My argument is that Hayek, Popper and other 'cold-war' liberals attack a partial representation of what is called utopian thinking which should not and does not exhaust the meaningful and useful senses in which utopian thought is possible and desirable. In this sense, I argue that the idea of utopia has useful purposes and needs rehabilitation in Western political thought. I argue further that much anti-utopian thought from liberal quarters is incoherent on the 
subject of utopia, and reflects the particular vision of society, connected through free trade and the unfettered development of capital, of classical liberalism.

\section{Hayek and Popper: utopianism, planning and holistic engineering}

Frederich Hayek, as the leading intellectual of the Austrian school, is a writer of enormous importance in influencing the negative view of utopian thinking in Western political culture. His major books, including The Road to Serfdom (1944), The Constitution of Liberty (1960) and the three volumes of Law, Legislation and Liberty $(1973,1976,1979)$ represent the most complete and coherent statement of the liberal principles of individualism, of a limited, constitutionally specified role for the state, of a faith in the market, and of the evils of all utopian conceptions and forms of planning. Hayek's intellectual project was to develop the economic theory of liberalism as well as to delegitimate the post-war theory of interventionism and oppose the extension of welfare rights throughout society.

Hayek maintains that the proper functioning of markets is incompatible with state planning or utopian conceptions of any sort, either full-scale socialism or the more limited conception of the welfare state. A full-scale rational socialism is impossible because it would have no markets to guide resource allocation. In addition, central planning of any form, he claims, is not practical because of the scale of centralised calculation any effective attempt at allocation would require. On this basis, Hayek (1944) contends that all forms of state action beyond the minimal functions of the defence of the realm and the protection of basic rights to life and property are dangerous threats to liberty which are likely to lead down the 'road to serfdom'.

His main arguments against central planning in relation to utopian blueprints are based on two claims: 1 . on its inefficiency, and 2. on the threat to freedom of the individual. It would be inefficient, in Hayek's view, because real knowledge is gained and true economic progress made as a consequence of locally generated knowledge derived from 'particular circumstances of time and place' and the state is not privy to such knowledge (Hayek, 1944, p. 521). The market then is the mechanism which best allocates resources in society. Planning ignores this localistic character of knowledge and interferes with the self-regulating mechanism of the market.

Also derived from von Mises, Hayek's work was characterised by a strong anti-socialism, most vehemently expressed in his opposition to Marxism, which he held did not constitute a rational means of organising an economy. For Hayek, economies are the outcome of spontaneous evolution and demonstrate the superiority of unregulated markets for creativity and progress as against all utopian conceptions or models of centralised planning. A spontaneous societal order such as a market order can utilise practical fragmented knowledge in a way in which a holistically planned order cannot. A spontaneous order emerges as a natural process. It can be observed in population biology of animal species, 
in the formation of crystals, and even in galaxies (Hayek, 1952, p. 180; 1967, p. $76 ; 1973$, p. 39; 1976, pp. 39-40). It is this idea that self-organising and selfreplicating structures emerge without design, and that knowledge about some parts of the structure permits the formation of correct understanding about the behaviour of the structure as a whole, that Hayek is most keen to emphasise. It underpins his rejection of Cartesian rationalism, his anti-historicism, his antifoundationalism, his strictures against state planning, and his anti-utopianism. In that the market is a spontaneous order, it displays a tendency to equilibrium, although an actual perfect equilibrium is never achieved but must be viewed as a constantly changing process of tending towards orderliness. This is not only with reference to economic life and the spontaneous emergence of markets, but also in social life in relation to the growth of language where we find the spontaneous formation of self-regulating structures, as well as in relation to the development of moral norms. Hence, as Gray points out, the emergence of spontaneous systems is 'somewhat akin to the generalisations of Darwinian evolution' (Gray, 1984, p. 31) in that Hayek maintains that 'selective evolution is the source of all order' (Gray, 1984, p. 32). Thus, in a market economy there is a real analogy to Darwinian natural selection in that the 'profit-loss system provides a mechanism for the elimination of unfit systems' (Gray, 1984, p. 32) with the proviso that, in contradistinction to Herbert Spencer or W.G. Sumner, natural selection is not solely about individuals but is also about groups and populations. Such a thesis incorporates Hayek's arguments that social institutions arise as a result of human action but not human design (the 'invisible hand' thesis); that knowledge embodied in practices and skills that is practical, tacit and local, is primary in terms of its epistemological status; and that there is a natural selection of competitive traditions whereby rules and practices that confer success come to replace those unsuited to the human environment. Following closely in the footsteps of von Mises, Hayek argues that any attempt to supplant market relations by public planning cannot avoid calculational calamities and is therefore doomed to failure.

Hayek's arguments against central planning have been seriously challenged.[8] While they may be persuasive against the idea of highly centralised decision making for the entire economy, beyond this his account of planning is simply a caricature, and the assessment of his legitimate empirical arguments is difficult to untangle from what is the deeply ingrained ideological nature of his anti-communitarianism. Hayek never considers whether markets and planning could (or should) co-exist. That is, whether there is not some middle-ground position between the 'serfdom' associated with state planning, and the 'freedom' associated with markets. As Jim Tomlinson (1990, p. 49, n. 3) notes:

in his 1945 article, ['The Use of Knowledge in Society'] Hayek typically

dismisses any mid-way point between centralised and decentralised

planning except 'the delegation of planning to organised industries, or, in

other words, monopoly' (p. 521). Plainly this does not exhaust the 
possibilities of levels of planning, nor does it provide a helpful starting

point for discussing mechanisms of planning.

Hence, as Tomlinson argues, it is not clear what scale of knowledge is deemed necessary by Hayek, for central planning to be effective. Apart from a persuasive argument against the idea of a single planning command centre for the whole economy, Hayek does not discuss levels of economic planning. As Tomlinson (1990, p. 41) continues:

His argument works with a simple polarity between individual (or decentralised) and centralised decision-making - but the degree of centralisation is never discussed, so it is unclear as to whether the argument applies to the one person business as to the multinational corporation.

The reader is also frequently left unaware of what freedom for Hayek involves. It is simply the state of not being coerced by governments or other people. It does not exclude huge inequalities of wealth and it does not prevent poverty and destitution. Why do the unintended consequences of the behaviour of the marketplace not count as an infringement of liberty? The answer is Hayek does not want to condemn but rather he wants to celebrate the unintended effects of the market on people's lives. What it does, in fact, is give an absolute priority to freedom as though this was the only value to be taken into account in society. Yet, for welfare liberals, liberty is only one of several desirable attributes of social organisation, others being equality, inclusion, participation, and justice. In exalting the liberty of the individual as his sole concern, not only does he deny that the state can have purposes and duties other than those arising from the purposes and interests of individuals, or of groups of individuals in market contexts, but if followed logically as a principle it would prevent forms of sensible state planning to constrain the excesses of the market, or to enable projects on behalf of communities (e.g. education and health). This is not to deny that there are many specific freedoms whose social value consists in allowing individuals to pursue their own ends, nor need we deny that the market is the best means of allocation for many resources. The central issue, not considered by Hayek, is how far the liberty of the individual and the market can be extended before choices in certain areas need to be limited because of the undesirable consequences of unrestricted individual liberty on society generally. That there could be general purposes, social benefits and public goods which are not provided for by markets, and which cannot be directly identified with individual interests, and which therefore must reside with the state, or the community, as the collective expression of people's interests, is simply not seriously considered by Hayek. His own arguments depend on a sharp dichotomy between markets and planning where mistakes and errors become 'entrenched' in the process of planning. Partly, this is due to the absence of local or contextual knowledge which actors in the marketplace have and state bureaucrats don't have, but why they should become 'entrenched' rather than 'correctable' is not clear. To use Hayek's (1945) 
language, while he celebrates knowledge of 'time and place' which is not accessible to planners, he gives no value to the benefits of 'aggregated' or 'statistical' knowledge, which enables perspective, which constitutes the equally important knowledge which 'planners' do have, and which is denied to agents in local contexts. Certainly, if planning sought to replace or override market mechanisms, one could see that would constitute a serious problem[9] but this does not mean that markets and planning can not complement and assist each other in turn, as Keynes argued in his theoretical justifications for the welfare state. Certainly, in Western countries, although state planning became central to the Keynesian welfare state settlements from the 1930 s to the 1970 s, one would be hard pressed to point to any significant erosion of liberty or 'road to serfdom' (i.e. totalitarian tendencies) that developed as a result.

\section{Popper}

Karl Popper argues against what he terms 'utopian social engineering' in favour of a 'piecemeal' approach in both The Open Society and Its Enemies (1945) and more systematically in The Poverty of Historicism (1961). The distinction between 'utopian' or 'holist' engineering and 'piecemeal engineering' is the distinction between two philosophical systems. As Popper represents it, the utopian approach says that the action is directed to an ultimate goal, end or aim, and agents act rationally when their actions accord with such an aim or goal. As Notturno (2003, p. 80) explains:

The utopian engineer must first identify his ultimate end. He must next choose the means most appropriate for attaining it, bearing in mind that they are merely means to the end and not the ultimate end itself. And he must then consciously and consistently pursue his ultimate end. Applied to practical political reform, the utopian approach says that we must identify our ideal state or society - the achievement which of which is presumably the ultimate goal of our political action - before we can do anything to reform our institutions or improve our situation.

In contrast to this large-scale social experimentation, piecemeal engineering favours a more limited, more pragmatic, 'trial and error' approach based upon an awareness of the limits of human knowledge and allowing adequate room for the correction of errors. As Notturno (2003, p. 80) states:

The piecemeal engineer ... searches for and fights against the greatest and most urgent evils of society, instead of searching and fighting for its ideal ultimate good. Instead of formulating an idea of his ultimate ideal state, he tries to identify the most pressing social problems in the state that actually exists. And instead of using his vision of the ideal state to bring them about, he tries to design and redesign social institutions that will alleviate actual suffering. The rationality of his action consists not in his consciously and consistently trying to bring about his ideal state, but in an experimental approach that acknowledges his own fallibility and the possibility that his 
actions may have consequences that are very different from what he intends. He thus proposes tentative solutions to problems, tests them, and tries to eliminate their errors.

In Popper's view the 'utopian approach is dangerous, and piecemeal engineering is the only viable way for policy design and change. Popper further suggests that the persecutions and undemocratic practices in totalitarian societies are the result of a holist conception of society and a holist approach to policy design and implementation. The holist, says Popper, believes that society is more than the sum of the individuals who comprise it, which gives a license to those who wish to curtail the rights and freedoms of the individual in the name of society's greater good (see Popper, 1961, pp. 76-93).

Popper's distinction between 'utopian' and 'piecemeal' is problematic on several grounds, and can be critiqued in terms of the general arguments I will make below. While policy formulations that lack democratic mandate, or aim to implement poor designs without consultation, or in huge sweeps, are clearly suspect, my problem is rather with Popper claiming that utopian engineering is unacceptable because it is executed in terms of a ideal pattern or state. In my view, this is unavoidable and must necessarily apply also to piecemeal engineering. It is not possible to frame policy except in relation to some ideal. By the same token, it seems somewhat far-fetched to imagine how any 'utopian strategy' could be executed 'all at once'. Even with policy in support of a revolutionary programme, planks of the programme must be implemented piece by piece. In terms of policy implementation at the level of day-to-day politics, then, the utopian and piecemeal policy plans will have much the same appearance. Popper would still claim that an inherent difference exists in that the piecemeal planner lacks any tie to a programmatic idea that influences the utopian planner. Yet my argument here is that liberals simply fail to see the programmatic ideal that lies 'repressed' within their own conception. With sectional policy reforms in Western countries, to do with say housing or health, the ideal of Western democratic communities constitutes a programmatic constraint, albeit sometimes at the level of the political unconscious. Or when, for instance, George Bush and Tony Blair illegally commence a war on Iraq, their policy initiative reflects the ideals of the Western world, as frequently stated by both men, with their frequent use of words like 'freedom', 'democracy' and the like. Such a world is both a world of the future and of the present. It is both an actually existing society and an ideal which guides and constrains. What the piecemeal planner does differently, in that he does anything differently at all, is proceed along lines that are more cautious, more circumspect, more in terms of trial and error, and with democratic legitimacy. Popper's real intended distinction, then, should be between policy planning that has this democratic, i.e. tentative, character, and that which hasn't, which is to say, between planning that is democratically mandated and executed, and that which is not. In a strictly epistemological sense, however, what should be noted is that both forms of policy are utopian. 
One further aspect of Popper's thought relevant to liberal views concerning utopianism and totalitarianism concerns his privileging of the binary dualism of 'open/closed' as in his two-volume The Open Society and Its Enemies (1945). Although this is an important dimension for consideration, its relevance will have to await further analysis.[10] Again, however, I am confident that the argument I am maintaining would hold valid: to the extent that Popper makes valid points, they relate to differences between the two systems as regards democracy (or its absence). Popper's (1992, p. 70) points on democracy are indeed insightful, especially his observation that rather than constituting 'rule by the people', democracy is better represented as a process by which individuals are protected against their leaders, and a mechanism by which their leaders can be replaced.[11] Yet it is only the presence or absence of democracy that makes a society 'open' or 'closed'. Beyond this, Popper's attempt to tie differences over democracy to fundamental philosophical and political outlooks simply reflects the cold-war politics of the time, as well as Popper's personal commitments to liberal politics and philosophy, and the resulting conflation of epistemological and ideological arguments entailed as a result.

\section{Utopianism and the Totalitarian State}

Utopianism, as liberals represent it, implies a positive conception of freedom and of the state's role in relation to freedom. This form of positive government was seen by liberals like Isaiah Berlin, as well as Hayek and Popper, as what essentially led towards totalitarianism. The classic liberal theory of totalitarianism sees it as a form of government that develops out of the structures of the positive state - that is, a state that decides to actively do things for its people, rather than maintain a laissez-faire stance. For liberals a positive conception of liberty leads the state to promote a single substantive ideal of the good - a description of man as a spiritual being whose ultimate rationality and reality are grounded in a unified spirit. This leads to a nation-state, which imposes a substantive conception of the good life, eradicating individuality by a concern with 'normcentricity'.

Positive freedom worries liberals. The positive view of freedom as active self-determination implies, says Berlin (1969), a distinction between two selves - a higher self that determines, and a lower self that is subject to determination. Berlin argues that in the history of political thought, it is all too easy for the higher self to become identified with the state or society, or with a particular political group's conception of what is 'rational'. Freedom then tends to become defined as obedience to what is rational, or obedience to the will of the state, or conformity to a predetermined pattern of thought or life. As a consequence, claims Berlin, positive freedom is transposed into the opposite of freedom: totalitarianism or tyranny.

In its extreme form, argues Nel Noddings (1996), it is claimed that the positive conception of liberty often leads to the promulgation of a single ideal - 
a description of 'man' as a spiritual being whose ultimate rationality and reality are grounded in a unified spirit. In this model, the state is seen as the expression of collective will (positive freedom), rather than the (mere) protector of individual liberties (negative freedom).

The total community $=$ fascism $=$ the nation-state. If the state is right, then there is no room for dissent, and liberty is equated with full immersion in the community. Liberals claim that individuality is wiped out by 'normcentricity'. In this way, Eric Hoffer maintained that communities foster 'unity' and 'self-sacrifice' along with conformity to established norms. In Hoffer's words:

Unity and self-sacrifice, of themselves, even when fostered by the most noble means, produce a facility for hating. Even when men league themselves mightily together to promote tolerance and peace on earth, they are likely to be violently intolerant towards those not of like mind. (Hoffer, 1951, p. 92)

If one examines other major authoritative studies on totalitarianism from a liberal perspective, one is also struck by their ideological and polemical nature. J.L.Talmon's The Origins of Totalitarian Democracy is a case in point. Talmon argues that totalitarian forms based on Messianism and utopianism emerged in the eighteenth century.

Men were gripped by the idea that the conditions, a product of faith, time and custom, in which they and their forefathers had been living, were unnatural and had all to be replaced by deliberately planned uniform pattern, which would be natural and rational.

Essentially, Talmon's (1952) argument is that almost all philosophical systems that are not based on classical liberalism have political implications that lead towards totalitarianism. These were based on the idea that a sole exclusive truth in politics postulated a preordained, harmonious and perfect scheme of things, recognised the political as the only plane of existence, saw human beings as social and political constructions, saw freedom as the realisation or attainment of a collective purpose, conceived of an enlarged state which actively constructed the conditions for human development. Further, 'empiricism is the ally of freedom, and the doctrinaire spirit is the friend of totalitarianism' (1952, p. 4). Centrally important is the idea 'of a homogeneous society, in which men live upon one exclusive plane of existence' (1952, p. 4), a unitary principle of social existence which Talmon traces to Hegel, Rousseau, Hellvetius, Holbach, Morelly, Mably, Sieyes, the Jacobins, Babeuf, and Buonarroti. While liberals fell back upon the trial-and-error philosophy, totalitarian Messianism hardened into an exclusive doctrine represented by a vanguard of the enlightened, who justified themselves in the use of coercion against those who refused to be free and virtuous (1952, p. 5).

William Montgomery McGovern (1946), in From Luther to Hitler: the history of Fascist-Nazi political philosophy, also identifies specifically non-liberal forms of thought as leading to authoritarianism and etatism. Amongst such 
thinkers or groups were Rousseau, the absolute idealists, Schlegel, Shelling, Hölderlin, and Hegel, the 'subjective' idealists, Fichte and Kant, and Kant's idealistic British disciples, who were the 'advance guard of the Fascist forces' (p. 133). Kant is seen 'as the forerunner of the neo-absolutist tradition' as although he was a liberal in his own times, his views could be 'twisted in such a way as to make them the foundation stone of etatism and authoritarianism'. Specifically here, Kant's maxim concerning the supremacy of reason, and that for laws to be valid they must accord with rational principles, bolstered the authoritarian tradition for it countenanced the disregard of the concrete wishes and desires of every section of the community (p. 141). Similarly, Kant's argument concerning the supremacy of universal moral law, where all human conduct should be regulated by the categorical imperative, reinforced the political importance of the views of the 'wise few' as being in a better position to judge over the wishes of the individual (p. 142). Following Rousseau, Kant argued that the state is a positive good and should represent the 'general good' of the whole society, and his views thus break with the individualism of the old order.

Ralf Dahrendorf maintains what is philosophically a similar thesis in his book Society and Democracy in Germany (1967). In asking 'how was National Socialism possible?', he looks to the contrast between 'Germany and the West', as reflected in the different intellectual value systems. By the West, Dahrendorf (1967, p. 11) means 'a set of values ... certain valued attitudes and patterns of social life'. Western values emphasise tolerance, imperfection, trial and error, neutrality, openness, plurality, an experimental and empirical approach to research, and that certain philosophical principles have a propensity to absoluteness. Amongst these latter are 'utopian constructions' (p. 139) which 'use techniques designed to suppress conflict' (p. 140) and as 'conflict is liberty' this amounts to a 'suppression of liberty'. In addition, the German idea of truth postulates a 'non-experimental conception of science', which while it stresses 'inner freedom' does not require 'political freedom'. Rather than deal with propositions individualistically, it consistently reaches for what amounts to an elite theory of truth:

... for the imaginary whole ... James B. Conant has a point when he remarks that in Germany people refer "with enthusiasm to the "total image", the "great order", the "great overview", to what is "universally valid", and they feel a certain disquiet about the confusing and somewhat disorderly diversity and ambiguity of things and events'. (1967, p. 151; citing Conant, 1957, p. 8)

In addition, the German people glorified the State as a unified and substantial will which suppressed all opposition. This was essentially Hegel's conception in The Philosophy of Right of 1821, where morality trumps liberty in Hegel's scheme. As Hegel writes (1942, p. 257): 
The State is the reality of the moral idea - the moral spirit as the revealed will, apparent to itself, substantial, which thinks and knows itself and accomplishes that which it knows and in so far as it knows it.

This view of the state was the logical derivation from 'absolute idealism' which Hegel and the absolute idealists drew from the monism of Spinoza, the rationalism of Plato, and the vital materialism of Leibniz. In such a conception the universe was conceptualised as a single reality, as an organic whole, where the whole determines the identity of its parts, and each part also determines the identity of the whole (Beiser, 2002, pp. 355-357).

\section{The Poverty of the Liberal Critique of Totalitarianism}

Certainly we can agree with liberals that an overly unified state, or too great an emphasis on consensus would pose a threat to the freedom of individuals, if such principles became effective at the level of actual politics. Beyond this, however, I believe their account of totalitarianism is weak and their arguments falter on a number of grounds.

Firstly, it is neither logically nor empirically entailed that a state that acts positively in terms of a specific substantive conception of the good, must ignore a respect for diversity and difference, or fail to respect the plurality of groups and subgroups in the wider society, or not be accountable in the last instance to the individuals who constitute it. To claim that the ideal of community is inextricably tied to an inexorable quest for unity or totality is a deeply mistaken premise. As postmodernists and pragmatists like John Dewey, and more recently Michael Sandel, have suggested, the good can accommodate difference. To suggest, therefore, that any state that does not confine itself to the minimum protection of individual liberties, but acts in terms of a general substantive vision, even if conceived in sophisticated terms, will unleash a pressure towards 'unity' or 'normcentricity' is a flawed argument, for it assumes that a theory of the good cannot exist at an abstract enough level to accommodate diversity or pluralism.

Secondly, the liberal theory of totalitarianism depends on presumptions that liberalism constitutes a neutral agenda where freedom is defined as the natural property of individuals outside of society. Based on this argument, writers like Berlin (1969) maintain that liberalism advocates no substantive conception of the good. The identification of a good is impossible, in Berlin's view, as individuals manifest such diversity of opinion over the nature of the good. Because of this irreducible pluralism over values and preferences, and consequent incompatibility over versions of the good, individual freedom is all that remains. It is only as a consequence of this axiom that that the state can be represented as the enemy, rather than the precondition, of freedom.

Notwithstanding Berlin's view, it can be claimed that liberalism itself implies a substantive conception of the good, and, in this sense, utopian conceptions of the ideal society are also embedded in liberal social relations. This is something which Hayek and Popper, operating within the epistemology 
of empiricism, believing that they operate from a neutral world where facts are neatly differentiated from values, never contemplated. The argument by liberals that within its policy prescriptions liberalism does not invoke a particular preferred shape to society, or that it does not advocate the establishment of a social good over and above what individuals desire cannot rule out substantive commitments about what society should be like. The point is made in one way by Luke Martell (1992, p. 156), who states:

It all sounds very nice until you realise that what it does, in effect, is to let in just another particular substantive vision of society as consisting of the sum total of individuals' preferences over which individuals have no overall control. In this sense, liberalism is in fact a highly substantive doctrine - one which posits a competitive individualist society immune to overall democratic direction.

Developing this line of thinking further, the neo-liberal organisation of society implies an ideal about the form of a best possible future which is nestled in the present relations of actually existing societies. Such an ideal can be discerned in the statements and visions of powerful world leaders and dominant global institutions such as the World Trade Organisation, the World Bank, or the International Monetary Fund in support of a model of international structural adjustment and policies of free trade.

Thirdly, the liberals' arguments technically rule out even more moderate forms of state regulation. For Hayek, as welfare rights are 'positive' rights, the welfare state is the start of the 'slippery slope', leading down 'the road to serfdom'. In his account Montgomery McGovern (1946) identifies moderate liberals such as Kant, and the 'British idealists' Green, Hobhouse and Bosanquet as contributing to totalitarianism. What is argued, in fact, is the proposition that almost any philosophical system other than pure classical liberalism results in etatism and authoritarianism. Hence 'Green harbours "germs of authoritarianism" (in spite of his strong support throughout his life for democratic control and the parliamentary system of government). Kant also supports authoritarian politics (in spite of his standing as one of the founders of liberal philosophy). In addition, Talmon identifies Mably with arguments for state regulation in defense of the poor and of "state control and interference with trade" (1952: 61) (especially in control of corn trade) as contributing to causing totalitarianism. Instead of the postulate of liberty [suggesting] the release of spontaneity ... we are faced with the idea of the State acting as the chief regulator ... with the purpose of enforcing ascetic austerity' (p. 62). There is a preoccupation with the general interest and the general good. It seems that for Talmon almost anything outside of pure classical liberal orthodoxy produces totalitarianism.

A further important point looms here in regards to the context and period in terms of which these liberals wrote, and which perhaps helps us understand liberal writers' views. As Steven Heyman (1992, pp. 81-82) claims with respect 
to Berlin's (1969) analysis of liberty, what is striking about it is the way it is distorted by the political circumstances in which the essay was written:

Berlin was writing in the late 1950s, at the height of the cold war. He casts the debate between negative and positive liberty as a crucial battle in 'the open war that is being fought between two systems of ideas' ... and between the political systems allegedly based on them - western liberal democracy and totalitarian regimes of the left and right ... With the passing of the Cold War, it may be easier to understand the relationship between positive and negative liberty in our political tradition.

Although we must applaud classical and neo-liberals for being against totalitarianism, their specific theoretical analysis as to what causes totalitarianism became mixed in with both 'left-right' politics and analysis of the role of the state in general, and 'cold-war' politics in particular. Although Heyman discusses this contention with specific regards to Berlin, I would claim the thesis is generally applicable to many others, to varying extents, including Hayek, Popper, and Plamenatz, Talmon, Dahrendorf, Montgomery McGovern, to name but a few. What liberals fail to notice is the way it manifests its own form of unitarism centring on reason, truth and liberal ideas. The way Popper, Hayek, Talmon, Montgomery McGovern and Dahrendorf reject all philosophical alternatives to classical liberalism, as leading to totalitarianism, reveals its own peculiar unitarist mantle.

With the passing of the cold war, it can be more easily seen that liberal explanations as to the origins of totalitarianism are misleading. To the extent that there are dangers inherent in human societies, such dangers inhere in all sorts of society, and it is difficult to identify such dangers as belonging specifically to a particular form and organisation of the state, in promoting the conditions for positive or negative freedom. While we can readily agree that too great an emphasis on normcentricity constitutes a potential threat to democracy, such dangers are present in both Western and Eastern societies. Any adequate explanation for the origins of totalitarianism must take adequate account of the historical, political, cultural and economic specificity of particular states at particular locations in history. What produces totalitarianism is not a particular gearing of state power (such as 'positive' or 'negative', or even 'holist', or 'piecemeal' engineering, in Popper's sense), but quite simply, the absence of democracy, or of the conditions which enable democracy to flourish. On this criteria, the Marxist-Leninist regimes of Eastern Europe failed in that they lacked a strong or deep conception of democracy, as well as the range of specific mechanisms by which democracy operates. As democracy is a structural arrangement, with specific techniques and mechanisms and processes that can be analysed, the best way to safeguard against totalitarianism is by ensuring that the state is a democratic state, and by seeking to deepen the specific senses in terms of which democracy operates.

This, I believe, is a far better explanation of totalitarianism than that which is provided in liberal criticisms which fail to sufficiently stress the 
processes through which mechanisms of democracy are institutionalised, in preference for explanations which stress the importance of philosophical and intellectual ideas as causative factors. While a neglect of democratic ideas and theory may of course impact upon the culture, the actual extent to which particular philosophers' views can be held to be causative forces is problematic. An overemphasis on 'normcentricity' or 'consensus' may certainly unleash dangerous political forces, but whether they do so in a specific country where such philosophical views are developed, or whether at times they have not operated in liberal cultures, is a moot point, and one that could prompt serious debate. For Talmon, however, it is taken for granted that such philosophical systems will cause totalitarianism. In his view (1952, p. 11), political Messianism and totalitarianism constitute a:

state of mind, a way of feeling, a pattern of mental, emotional and behaviouristic elements, best compared to a set of attitudes engendered by a religion. Whatever may be said about the significance of the economic or other factors in the shaping of beliefs, it can hardly be denied that the allembracing attitudes of this kind, once crystallized, are the real substance of history.

This, needless to say, advances a highly contentious view, and places an overemphasis on intellectual ideas as influencing the culture, which in turn influence the politics. Such factors as institutional mechanisms, the existence of checks and balances, and the actual way that power is distributed in societies, would seem to me to be somewhat neglected in these accounts.This introduces yet a further weakness of liberal explanations for totalitarianism. In that their explanations attribute a failure of democracy to the way the state acts, the arguments are couched in terms of a general timeless theoretical argument, rather than as a specific empirical analysis of particular societies in particular historical circumstances. In this sense, the identification of particular non-liberal philosophical viewpoints is meant to explain totalitarianism in all countries and at all times, no matter how different in terms of history and tradition. It is also not asked whether such political philosophies are compatible with democracy, or whether in fact better models of democracy could not be constructed in their light.[12] Such general philosophical broadsides are no substitute for a detailed historical analysis as to why discourses of democracy did not take root, or prevent abuses of power, in a number of different countries, in the first half of the twentieth century.[13]

\section{Foucault and Totality}

The idea of a uniform and totalistic society, uniformly challenged by liberals, was also opposed by Michel Foucault. In opposition to totalising approaches, Foucault (1972, pp. 9-10) draws a methodological distinction between total and general history, giving his allegiance to the latter. The central differences between the approaches are: 
The project of total history is one that seeks to reconstitute the overall form of a civilization, the principle - material or spiritual - of a society, the significance common to all the phenomenon of a period, the law that accounts for their cohesion ... [G]eneral history on the contrary, would deploy the space of dispersion ... it speaks of series, divisions, limits, differences of level, shifts, chronological specificities, particular forms of rehandling, possible types of relation ... . The problem which defines the task of general history is to determine what form of relation may be legitimately described between these different series.

In terms of political relations and utopian theorising, Foucault's (1991, p. 18) opposition to 'totality' can be seen expressed in his opposition to Habermas, for instance:

[In Habermas' work] there is always something which causes me a problem. It is when he assigns a very important place to relations of communication and also to functions that I would call 'utopian'. The thought that there could be a state of communication which would be such that the games of truth could circulate freely, without obstacles, without constraint, and without coercive effects, seems to me to be Utopia. It is being blind to the fact that relations of power are not something bad in themselves, from which one must free oneself. I don't believe there can be a society without relations of power ... . The problem is not of trying to dissolve them in the utopia of a perfectly transparent communication, but to give oneself the rules of law, the techniques of management, and also the ethics, the ethos, the practice of self, which would allow these games of power to be played with a minimum of domination. (emphasis added)

For Foucault, the political is not equated with the rational as a unified consensual form, for such form ignores diversity. Rather, difference implies conflict in both practices and perspectives, which does not maintain that one way of living is superior to another. Essentially, then, Habermas' view ignores the reality of diversity and conflict in preference for what is a new rationalist conception of utopia. As with Plato or Hegel, Habermas, in asserting the intersubjective nature of rationality, fails to respect difference. For Habermas, rather, differences are filtered through the internalised procedures of government whereby the parts of the polis are represented as different parts of a unity. For Foucault, the state plays only a pragmatic role, not of imposing the rational on the irrational but of arbitrating conflicts between different groups. In this sense, unlike Habermas, politics is not a means of integration based upon procedural considerations. The consensus reached is not rational but functionally expedient and provisional, and continuing conflict is not a failure of communicative rationality but an indication of diversity.

For Foucault, the opposition to Marxism and Hegelianism is in terms of the unitary notion of 'totality', which seeks to explain the individual instances of a culture as decodable parts of the whole totality or system. This was the 
approach of Hegel, as well as Marx, which seeks to analyse history and society as totalities, where the parts are an expression of the whole - hence the notion of an expressive totality. It is also the approach of Spinoza and Rousseau, where the ideal of community expresses a longing for harmony among persons. For Foucault such an approach represents 'the Rousseauist dream' of:

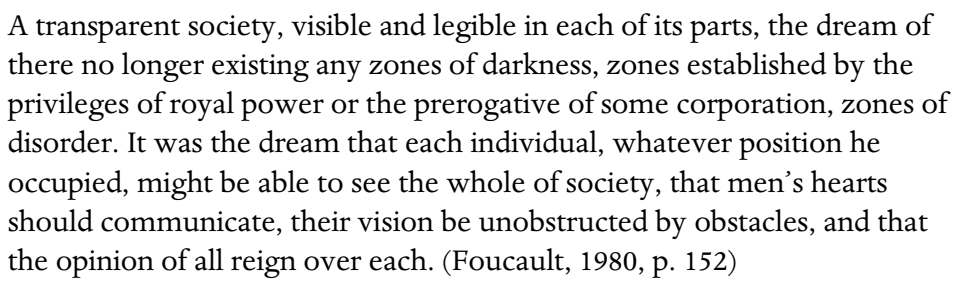

In The Archaeology of Knowledge (1972, p. 114), Foucault explains this critique of unitarism, which he sees as having implications for totalitarianism, as being a 'central theme'. His concern was to uncouple the linkage that existed within systems of thought such as Hegelianism, as has preoccupied writers in both the liberal and continental traditions of thought, between metaphysical holism and terror. By so doing, Foucault attempts to salvage a pluralist political ontology premised upon a holist epistemology and a conception of the historical and social constitution of subjects, both as individuals and as collectivities. In this, Foucault's historical-critical approach is an experimental one. It rejects 'radical and global' forms of analysis, as:

we know from experience that the claims to escape from the system of contemporary reality so as to produce the overall programs of another society, of another way of thinking, another culture, another vision of the world, has led only to the return of the most dangerous traditions.

(Foucault, 1984b, p. 46)

Rather than seek to explain all phenomena in relation to a single centre, Foucault is interested rather to advance a polymorphous conception of determination in order to reveal the play of dependencies in the social and historical process. Hence, in opposition to the themes of totalising history, Foucault substitutes what he calls a 'differentiated analysis':

Nothing, you see, is more foreign to me than the quest for a sovereign, unique and constraining form. I do not seek to detect, starting from diverse signs, the unitary spirit of an epoch, the general form of its consciousness: something like a Weltanschauung. Nor have I described either the emergence and eclipse of formal structure which might reign for a time over all the manifestations of thought: I have not written the history of a syncopated transcendental. Nor, finally, have I described thoughts or century-old sensitivities coming to life, stuttering, struggling and dying out like great phantoms - ghosts playing out their shadow theatre against the backdrop of history. I have studied, one after another, ensembles of discourse; I have characterised them; I have defined the play of rules, of 
transformations, of thresholds, of remanences. I have established and I have described their clusters of relations. Whenever I have deemed it necessary I have allowed systems to proliferate. (Foucault, 1978, p. 10)

While this entails an important theoretical point in reference to Foucault's rejection of theories of totality, as long as the qualifications posited above are kept in mind, Foucault accepts that a consensus model can operate in politics as a form of 'critical principle'. The issue was put to him put to him in 1983 by a group of interviewers including Paul Rabinow, Charles Taylor, Martin Jay, Richard Rorty, and Leo Lowenthal:

Q. If one can assume that the consensus model is a fictional possibility, people might nonetheless act according to that fiction in such a way that the results might be superior to the action that would ensue from the bleaker view of politics as essentially domination and repression, so that although in an empirical way you may be correct and although the utopian possibility may never be achievable, nonetheless, pragmatically, it might in some sense be better, healthier, freer, whatever positive value one uses, if we assume that the consensus is a goal still to be sought rather than one that we simply throw away and say it's impossible to achieve.

M.F. Yes, I think that is, let us say, a critical principle ...

Q. As a regulatory principle?

M.F. I perhaps wouldn't say regulatory principle, that's going too far, because starting from the point where you say regulatory principle, you grant that it is indeed under its governance that the phenomenon has to be organised, within limits that may be defined by experience or the context. I would say, rather, that it is perhaps a critical idea to maintain at all times: to ask oneself what proportion of nonconsensuality is implied in such a power relation, and whether that degree of nonconsensuality is necessary or not, and then one may question every power relation to that extent. The farthest I would go is to say that perhaps one must not be for consensuality, but one must be against nonconsensuality. (Foucault, 1984a, p. 379)

Foucault's pluralism shows that it is in fact not necessary to dispense with a conception of the good so long as it is complexly mediated and democratically structured to allow respect for difference. The good as conceptualised in Greek ethics saw virtue as an ultimate end, or objective form, as 'that to which reason apprehends', as 'the agent's interest well understood' (Larmore, 1996, p. 21). As Martha Nussbaum (1995, p. 457) expresses it, the good is a 'thick, vague conception' which can be construed to represent the formal needs and requirements of humans, such as the need to eat, the need for emotional sustenance, the need for shelter, and so on.[14] While these have certain effects on individuals which constrain their wishes and desires, and their ethical choices, they are not incompatible with diversity or difference. While people 
have needs for food and shelter, they will satisfy these in countless different ways, although there will also be certain common principles that all must respect, such as the principle of non-interference. Such a conception is not incompatible with democracy however, and Foucault's (1991) working assumption of the equalisation of power relations[15] as the principle by which 'self-creation' (Foucault, 1986) and parrhesia (Foucault, 2001) are made possible gives pride of place to democracy as rule by which order and freedom are able to operate.

\section{Rehabilitating Utopianism Post 9/11}

While liberal strictures regarding too great an emphasis on consensus may well be heeded, it would seem to me that there is no necessary connection between such utopian models and totalitarian politics. This, it might be argued, is especially so in a global world where forms of philosophical monism centring on the nation are no longer so probable. Indeed, utopian models need not be undemocratic; neither must they be based on forms of philosophical monism, or absolute idealism. What is clear from examining liberal criticisms is that they are concerned not with utopias in general, but only with a specific type of utopianism - a form that emerged first in the Renaissance, and became justified in the late eighteenth century in terms of philosophical monism and absolute idealism. Rather than point to the substantive content of political philosophies that contributed to totalitarianism, what is more relevant today in accounting for authoritarian political relations is that lack of theoretical work on democracy and the absence of democratic mechanisms and processes in the institutional structures of societies. What causes totalitarianism, to put it bluntly, is simply an absence of democracy. An absence, firstly, at the level of institutionalisation, and, secondly, at the level of theoretical and intellectual production.

In my view, given the changing concerns relating to security and freedom in the world post $9 / 11$, utopian models offer a unique methodological vehicle for redesigning the balance between individual freedom and the needs of community. Utopian models offer us a bulwark against totalitarianism in that they enable values such as freedom, equality, justice and security to be retheorised in the context of an 'imagined' community rather than considered atomistically as a series of analytical relations. Although totalitarian or authoritarian politics is an ever-present danger, and has taken various monstrous forms in the last 100 years, the view I want to suggest is that outside of the 'cold-war' frame of reference, we must consider the power distortions that generate totalitarian rule to constitute a potential danger in all types of societies. Whether it is the bold action of a particular state governor, or private company, or of national leaders who illegally commit their countries to war (as in the war on Iraq, for example), the undemocratic misuse of power, which takes various forms, is an ever-present danger in all societies. As Foucault (1994, pp. 535-536) has observed, for instance: 
Of course fascism and Stalinism expanded their effects to hitherto unknown dimensions, and it is, if not to be rationally expected, at least to be hoped, that we never see their like again. They are therefore unique phenomena, but it cannot be denied that, in many respects, fascism and Stalinism simply extended a whole series of mechanisms that already existed in the social and political systems of the West. After all, the organization of great parties, the development of political apparatuses, and the existence of techniques of repression such as labor camps, all that is quite clearly the heritage of liberal Western societies, and all Stalinism and fascism had to do was to stoop down and pick it up.

In order to combat such forces, both the monstrous forms of fascism and Stalinism, as well as all other less serious abuses of political power, the best answer, in my view, must be sought in the strengthening or deepening of democracy, both nationally and globally, and envisaging new forms of democracy as a means of achieving this.

In this process, utopian modelling can be more useful than liberal philosophising. As Kenneth Keniston (1970, p. 300) says, the poverty of liberalism is that it constitutes a 'privatization of utopia'. Further (1970, p. 301):

The deflection of the Utopian Spirit ... leads to a withdrawal of idealism from the areas of our shared lives that most need a Utopian vision.

As a consequence liberalism cannot constitute grounds for guiding political action in a global age. Freed from the spell of illusion and dreams they fall prey to political paralysis and nihilism. In Spragens's (1981, p. 5) view there has been an 'incapacity of liberalism's deepest assumptions - ontological, epistemological and anthropological - to sustain its finest aspirations and ideals'. The upshot of all of its theorising on the subject is an opposition to any form of positive or regulatory state at all. Any form of regulation in the interests of equality or justice is cast down the slippery slope to serfdom, rejected in relation to the bogey of totalitarianism.

Central to its own 'repressed' utopian vision is the individualism of its epistemology, its ideal of a single language and a unified vision for all the sciences, the rationalism of its philosophical approach, distinct limits on the role of theory and imagination, its commitment to the uncritical pursuit of a narrowly conceived freedom, an image of man that is too rationalistic, as well as a peculiar form of social amnesia, which cuts people off from both past and community. Both Descartes and Locke warrant a reliable foundation for knowledge of 'clear and distinct' ideas to be taken as 'self-evident' truth. Although Descartes saw the Cogito, and Locke experience, as the starting point, in both cases direct simple ideas constituted the atomic components of reliable knowledge in thoroughly individualistic terms. Yet such an epistemology gave rise to a new philosophical dualism of its own. It was now divided into 'us vs. them', 'reliable concrete knowledge vs. ideology', 'practice vs. theory', 'individual vs. community’. As Spragens (1981, p. 45) puts it: 
We might characterise this dominant paradigm ... as epistemological manicheanism. In its relation to the human understanding the world was divided into two. On the one side lay the kingdom of light, the land of the intelligible. In it, all was transparent and comprehensive with certitude. On the other side lay the kingdom of darkness, the land of the unintelligible. In it all was impenetrable to the best efforts of the human mind.

In the seventeenth century such views could also be seen as progressive and utopian. In this sense they were related to politics, for they believed, says Spragens (1981, p. 48), that the 'triumph of reason would lead to the relief of man's estate. Like Plato, the adherents of the new rationalism offered their knowledge as a crucial resource for political regeneration'. As Spragens (1981, p. 57) continues:

The political benefits from the new epistemology were expected to be direct as well as indirect. The spread of enlightenment, it was hoped, would produce some crucially important, specifically political dividends. The miscarriages of politics had been caused by distortions in man's beliefs about himself and the world.

Although liberalism thus provided a convenient epistemology for the development and spread of science over several centuries, the contradictions between its ontological and epistemological principles on the one hand, and its aspirations on the other, were to become progressively apparent. In a global era, its failure to be able to theorise or accommodate the collective dimensions of life becomes a major weakness. In relation to politics, as Spragens (1981, p. 7) tells us, liberals naively conceptualise power 'sustained by the happy faith that the hand of nature could produce an optimum social equilibrium'. In a similar way liberals are too frequently naive concerning the political implications of economic forces. The conception of the role of the state they are left supporting, as the only one that is safe in terms of democracy, is a minimal form of laissez-faire. Stuck within an individualist ontology, they are unable to account for, or accommodate, the collective dimensions of life. The conception of democracy that they advocate is a purely formal one, one that is compatible with individualistically conceived liberty, which avoids questions concerning the sharing of resources or the benefits of the world's wealth. In such a model, as Spragens (1981, p. 10) says, 'liberal premises are a stumbling block to liberal aspirations'. Such a model, although formally democratic, as represented by contemporary liberal and conservative theorising, is not deeply democratic. In addition, it allows inequalities to develop unchecked, and as we enter the twenty-first century it becomes increasingly dominated by powerful and pervasive transnational interests. Such a world, post 9/11, confronts the erosion of traditional liberal values such as privacy and freedom, as it becomes preoccupied with the new 'imperatives' of security. And it becomes culturally and environmentally unsustainable, and personally unrewarding. In this context structures of the social and the public sphere become more deeply privatised. 
It is no coincidence that in this context utopian theorising has once again assumed popularity. Given the widespread 'nihilism of our times', as Judith Green (1999, p. vii) argues, there is a need to deepen our understanding of democracy, moving beyond liberal fears. Utopian models, while they may harbour dangers, may also enable us to understand how a deeper conception of democracy might be possible. As I have written elsewhere (Olssen et al, 2004), what is necessary today is to understand democracy as a comprehensive discourse premised upon a reconstructed public sphere. Such a conception is in keeping with Dewey's sentiment, as Green (1999, p. ix) expresses it, that 'the cure for the ailments of democracy is more democracy'. Democracy as conceptualised in such a model is not simply a justification, but a transformative ideal that can always be improved, or deepened still further (Green, 1999, p. x). In my own account, democracy as a comprehensive discourse includes 1. safety and security; 2. freedom and autonomy; 3. inclusion and participation; 4. fairness and justice; and 5. equality of resources and capabilities.

Safety and security express themselves in children's telephone 'help-lines', women's refuges, or human rights accords for the treatment of ordinary citizens, or prisoners, and so on. Inclusion warrants that no one is excluded from democratic entitlement, and constitutes the basis on which safety and security can be assured in the development of a reconstructed public sphere. Freedom incorporates freedom from domination and freedom for the development of capabilities. Justice and fairness promise treatment in a public arena according to publicly stated criteria embodied in constitutional laws and rules. Equality of resources and capabilities ensures opportunities and conditions for development for all. In that treating people fairly and reasonably on the basis of respect minimises terrorism and increases the chances for survival, democratic justice based on an equalisation of power and nondomination becomes an objective good. It is in the interests of both the individual and the collectivity. In an age of terrorism, where a global Leviathan is clearly an unsavoury possibility, a comprehensive discourse of democracy becomes the best answer to the Hobbesian problem of order.

Such a conception requires institutions committed to conflict resolution, ongoing debate and communication, as well as the mutual survival of different traditions. Such a democratic conception is not utilitarian, but presupposes rights and entitlements which are universally given to all. Rights in this conception are not natural, but are given by the state as the collective expression of the will of the people. Such rights are necessary to self-creation and constitute recognition that a space of autonomy is necessary to selfdevelopment of both individuals and groups. The events of 9/11 may hopefully reintroduce a concern for rights, and other themes within liberal constitutionalism, as fundamental to the emancipatory and progressive concerns of a genuinely democratic world order. Such a conception of democracy also underpins multicultural rights by recognising different group aspirations yet underpinning them with a rights culture. Unlike liberal conceptions of democracy, it is not insensitive to diversity and does not seek 
cultural homogeneity through the uniform application of a single standard or rule.

\section{Deepening Democracy through Education: a new utopistics}

If post 9/11 makes democracy of more pressing concern; a concern with utopian modelling as a way of deepening democracy can move well beyond a narrow formal theory of liberal and conservative theory. If at the level of theory, our conception of democracy posits certain general principles, which allow for a degree of diversity and pluralism, our procedural view of democracy is as a multifaceted array of mechanisms and processes instituted to ensure the inclusion, security or safety as well as development and opportunities of all individuals and groups. In this respect research on utopia needs to focus of the means of deepening democracy to satisfy these goals. As a way of concluding this article, it might look to include research on all or any of the following themes:

The concern with equality: the development of any conception of democratic justice must seek to deal with rather than avoid issues to do with distribution of resources and life chances. Given a rejection of the classical liberal fiction regarding entitlement to property based on a model of pre-social, possessive individuals who 'owe nothing to society', it is important to theorise the implications of a social ontological framework of community for considerations of democratic justice as it pertains to distributional ethics. Community in this sense is definable as an all-encompassing arena without fixed borders or unity, which comprises an assortment of values, norms and institutions that enable life to be lived. Such a conception of community recognises social ties and shared values, as well as practices of voluntary action and public institutions like education which constitute the conditions for stability and reproduction of society. Although neo-liberal philosophers like Nozick (1975) have shifted political philosophy away from a concern with issues of distributive justice in recent years, my own view is similar to the nineteenth-century social democrat L.T. Hobhouse (1911), who held that one's entitlement to rewards and gain must be balanced by one's obligation to society. What liberal conceptions of democracy obscured, in Hobhouse's view, was the interdependence between individuals and the social structure or for the social and moral obligation of the society (acting through the vehicle of the state) to assist in arranging the social futures of each rising generation. As he argued in his book Liberalism (1911, pp. 189-190), in his justification for redistributive policies of progressive taxation, the state has an obligation to enforce reasonable conditions of equality on the basis that while a society should provide the conditions for enterprise, all individuals are correspondingly indebted to society for the conditions and structures provided, and, on this basis, individuals should contribute in direct proportion to the luck or good fortune they experience. 
The role of the state: The role of the state should be concerned with guaranteeing both negative freedom and positive freedom. Negative freedom involves the state's responsibility for ensuring the universal entitlements to safety and reasonable autonomy for all. The trade-off in respect to privacy will be necessitated to the extent that these obligations are threatened. To the extent that greater surveillance is deemed necessary, the proposals must be themselves subject to democratic processes that ensure visibility, openness, deliberation and debate.

The state's obligations as regards positive freedom involve it in developing opportunities based on people's rights to inclusion and the development of their capacities. This obligation gives the state a role in the provision of social services, healthcare, and education. In brief, the role for the positively geared state lies in relation to socially directed investment decisions, to provide for the general conditions for all species' needs and development, including education and training, and to create and maintain quality infrastructure such as schools, hospitals, parks and public spaces.

The development of civil society: a vibrant civil society can constitute a check on the powers of government. Civil society refers to that sector of private associations relatively autonomous from the state and economy, which spring from the everyday lives and activities of communities of interest. Clearly, one principle of democracy is the idea of multiple centres of power, and of their separation, as suggested by writers like Montesquieu and de Tocqueville. More recently, it can be gleaned from Foucault's work that democracy consists in an 'equalisation' of power relations. Another principle of democracy is the right to contest, challenge or oppose. Institutions of civil society, as writers like Paul Hirst (1995) have maintained, can be seen to constitute an important powerful network of quasi-independent associations, which can strengthen democratic rule through checking the power of the state. If democracy is rule by the people, the ability, and opportunity to contest power, as Philip Pettit (1997) has put it, or of parrhesia, or speaking the truth to power, as Michel Foucault (2001) has put it, is itself one of democracy's crucial rights, indeed its very condition. According to Cohen \& Arato (1992), civil society strengthens democracy in both a defensive and offensive sense. The defensive aspect refers to the way that associations and social movements develop forms of communicative interaction that support the development of people's identities, expand participatory possibilities and create networks of solidarity. The offensive aspect refers to how associational networks and institutions come to exert influence on, and constitute checks to, the state, and to each other.

The role of education: the role of education is crucial for democracy, as educational institutions, whether compulsory or post-compulsory, intersect with, and therefore mediate between, institutions like the family and those of the state and the economy. Although formal institutions of education have 
been in the main public institutions, there is an important sense in which they are semi-autonomous from the state. This is not the neo-liberal sense, where management and administration are devolved to the local school, but the sense in which the schools are located in, and represent local community groups. In this sense, schools are important as democratic organisations, through the particular way that they are connected to communities, through their ability to empower families, and involve minority groups in participatory projects. Education is also crucial as the central agency responsible for the production of democratic norms such as trust and political decision making. This is to say, as Mill (1910) recognised in Representative Government, educational institutions are important as sites where democracy and self-government are learned. Deliberative democracy is especially complex, for it involves not just norms and procedures of debate but norms and procedures of contestation, inclusiveness, tolerance, compromise, solidarity with others, generosity, care, the operations of forums, and of checks and balances, the use of sanctions and screens, and the separation of powers. In the republican tradition, schools are instrumental in the development of civic virtue and habits of good citizenship. This is what signals the real importance of the 'knowledge economy'. For education is essentially important in its role of constructing democratic civic norms, and this must become one of the central aims of government policy in this regard. It is not a case of 'brainwashing' or 'socialisation' but of teaching skills and establishing models of civic conduct based on tolerance, deliberation, conflict resolution, give and take, and trust. While educational processes depend upon fairness of political processes, and in the distribution of economic resources, education is necessary to construct the network of norms that permit both the market and democracy to function. As Philip Pettit (1997, p. 255) puts it, education represents a 'stark choice between the invisible hand and the iron hand: between a strategy of marketing and a strategy of management'. It is this reason of course why education should ideally be public, universal, compulsory and free. For if education is vital in constructing norms that nurture the market, it cannot be itself subject to the market's disorganising effects.

\author{
Notes \\ [1] Thomas More, Utopia (1516). \\ [2] Johan Eberlin von Günzburg, Wolfaria (1521). \\ [3] Anton Francesco Doni, Il Mondo Savio e Pazzo (1552). \\ [4] Tommaso Campanella, La Città del Sole (1602). \\ [5] Johann Valentin Andreae, Christianopolis (1619). \\ [6] Robert Burton, A Utopia of Mine Own (1621). \\ [7] Francis Bacon, New Atlantis, (1624). \\ [8] See, for instance, Gray (1984), Hindess (1990), Tomlinson (1990).
}


[9] Hayek's argument against early communist regimes which sought to replace markets with state planning are indeed valid, but accepting this argument, which was relevant only at the time Hayek wrote, does not logically or empirically coerce a view that planning in all forms should be (or indeed could be) done away with.

[10] Such an analysis would take substantial space, and would be beyond the scope of an article such as this.

[11] My own conception of democracy, introduced below, extends this insight, except I will represent it as a comprehensive discourse which protects all, not just against leaders, but against all, through the rule of law. It is therefore a discourse which ensures rights, entitlements, security and freedom.

[12] Most of the philosophical viewpoints criticised by liberals, e.g. Rousseau's, were, in their own terms, specifically democratic formulations, intended to address problems or weaknesses within existing philosophical theories. The liberal critique is, in this sense, directed against the effects that liberals interpret these theories to have, rather than to deliberate arguments against democracy by the philosophers concerned. Of course, some (e.g. Plato) did maintain antidemocratic views.

[13] In nearly all liberal philosophical accounts there is no mention of local factors specific to the countries involved, or to the rise of such discourses as eugenics throughout the Western world.

[14] Her list also comprises such things as the requirements of practical reason and cognitive development. Nussbaum's conception is perfectionist in that it specifies an objective conception of the good, which comprises the core human capabilities consisting of 'the most important functions of human beings in terms of which human life is defined' (1995, p. 457). Such a conception is not metaphysical in that it does not claim to derive from a source exterior to human beings in history. Rather, she says (1995, p. 457) it is 'as universal as possible' and aims at 'mapping out the general shape of the human form of life, those features which constitute life as human wherever it is'.

[15] In his interview 'The Ethic of Care for the Self as a Practice of Freedom', Foucault (1991) suggests that liberty and ethics are not possible where domination strategies are fixed and oppressive (p. 3), and that the ideal situation for self-creation is where 'games of power can be played with a minimum of domination' (p. 18). I have interpreted and argued that this supports a broad normative principle of 'the equalisation of power relations', which can be extracted from Foucault's analysis (see Olssen, 2002).

\section{Correspondence}

Dr Mark Olssen, Department of Educational Studies, University of Surrey, Guildford GU2 7XH, United Kingdom (m.olssen@surrey.ac.uk). 


\section{References}

Beiser, F.C. (2002) German Idealism: the struggle against subjectivism, 1781-1801. Cambridge, MA: Harvard University Press.

Berlin, I. (1969) Four Essays on Liberty. Oxford: Oxford University Press.

Cohen, J.L. \& Arato, A. (1992) Civil Society and Political Theory. Cambridge, MA: MIT Press.

Dahrendorf, R. (1967) Society and Democracy in Germany. New York: Doubleday Anchor.

Eliav-Feldon, M. (1982) Realistic Utopias: the ideal imaginary societies of the Renaissance 1516-1630. Oxford: Clarendon Press.

Foucault, M. (1972) The Archaeology of Knowledge. London: Tavistock.

Foucault, M. (1978) Politics and the Study of Discourse (translated by C. Gordon), Ideology and Consciousness, 3, pp. 7-26.

Foucault, M. (1980) Power/Knowledge: selected interviews and other writings 1972-1977 (edited by C. Gordon). Brighton: Harvester Press.

Foucault, M. (1984a) Politics and Ethics: an interview (translated by C. Porter), in P. Rabinow (Ed.) The Foucault Reader, pp. 373-380. New York: Pantheon.

Foucault, M. (1984b) What is Enlightenment? (translated by C. Porter), in P. Rabinow (Ed.) The Foucault Reader, pp. 31-50. New York: Pantheon.

Foucault, M. (1986) The Care of the Self: history of sexuality, Vol. 3 (translated by R. Hurley). New York: Pantheon.

Foucault, M. (1991) The Ethic of Care for the Self as a Practice of Freedom: an interview (translated by J.D. Gauthier), in J. Bernauer \& D. Rasmussen (Eds) The Final Foucault, pp. 102-118. Cambridge, MA: MIT Press.

Foucault, M. (1994) La Philosophie Analytique du Pouvoir, in D. Defert \& F. Ewald (Eds) with J. Lagrange Dits et Ecrits: 1954-1988, four volumes, vol. 3, no. 232, pp. 534-551. Paris: Editions Gallimard.

Foucault, M. (2001) Fearless Speech (edited by Joseph Pearson). Los Angeles: Semiotext(e).

Gray, J. (1984) Hayek on Liberty. Oxford: Blackwell.

Green, J.M. (1999) Deep Democracy: community, diversity, transformation. Lanham: Rowman \& Littlefield.

Hayek, F.A. (1944) The Road to Serfdom. London: Routledge \& Kegan Paul.

Hayek, F.A. (1945) The Use of Knowledge in Society, American Economic Review, 35(4), pp. $519-530$.

Hayek, F.A. (1952) The Sensory Order. London: Routledge \& Kegan Paul.

Hayek, F.A. (1960) The Constitution of Liberty. London: Routledge \& Kegan Paul.

Hayek, F.A (1967) Studies in Philosophy, Politics and Economics. London: Routledge \& Kegan Paul.

Hayek, F.A. (1973) Law Legislation and Liberty. Volume 1. London: Routledge \& Kegan Paul.

Hayek, F.A.(1976) Law Legislation and Liberty. Volume 2: the mirage of social justice. London: Routledge \& Kegan Paul. 
Hayek, F.A. (1979) Law, Legislation and Liberty. Volume 3: the political order of a free society. London: Routledge \& Kegan Paul.

Hegel. G.W.F. (1942) The Philosophy of Right (translated by T.M. Knox). Oxford: Clarendon.

Heyman, S. (1992) Positive and Negative Liberty, Chicago-Kent Law Review, 68, pp. 81-98.

Hindess, B. (1990) Liberty and Equality, in B. Hindess (Ed.) Reactions to the Right, pp. 7-31. London: Routledge.

Hirst, P. (1995) Can Secondary Associations Enhance Democratic Governance?, in J. Cohen \& J. Rogers (Eds) Associations and Democracy: the real utopia's project, Vol. 1 (series editor Erik Olin Wright), pp. 101-112. London: Verso.

Hobhouse, L.T. (1911) Liberalism. London: Williams \& Norgate.

Hoffer, E. (1951) The True Believer. New York: Harper \& Row.

Keniston, K. (1970) The Uncommitted. New York: Dell.

Larmore, C. (1996) The Morals of Modernity. Cambridge: Cambridge University Press.

Martell, L. (1992) New Ideas of Socialism, Economy and Society, 21, pp. 152-172.

Mill, J.S. (1910) Representative Government. New York: Everyman.

Montgomery McGovern, W. (1946) From Luther to Hitler: a history of Fascist-Nazi political philosophy. London: George Harrap.

Noddings, N. (1996) On Community, Educational Theory, 46, pp. 245-267.

Notturno, M.A. (2003) On Popper. South Melbourne: Thompson/Wadsworth.

Nozick, R. (1975) Anarchy, State, Utopia. Oxford: Blackwell.

Nussbaum, M. (1995) Human Functioning and Social Justice: in defence of Aristotelian essentialism, in D. Tallack (Ed.) Critical Theory: a reader, pp. 449-472. New York: Harvester Wheatsheaf.

Olssen, M. (2002) Michel Foucault as 'Thin' Communitarian: difference, community, democracy, Cultural Studies/Critical Methodologies 2, pp. 483-513.

Olssen, M., Codd. J. \& O’Neil, A.-M. (2004) Education Policy: globalization, citizenship, democracy. London: Sage.

Pettit, P. (1997) Republicanism: a theory of freedom and government. Oxford: Oxford University Press.

Popper, K.R. (1945) The Open Society and Its Enemies. Two volumes. London: Routledge \& Kegan Paul.

Popper, K.R. (1961) The Poverty of Historicism. London: Routledge \& Kegan Paul.

Popper, K.R. (1992) The Lesson of This Century (interview by Giancarlo Bosetti). London: Routledge.

Spragens, T.A. (1981) The Irony of Liberal Reason. Chicago: University of Chicago Press.

Talmon, J.L. (1952) The Origins of Totalitarian Democracy. London: Mercury Books.

Tomlinson, J. (1990) Market Socialism: a basis for socialist renewal?, in B. Hindess (Ed.) Reactions to the Right, pp. 32-49. London: Routledge.

Wright, E.O. (1995) Preface: the Real Utopias Project, in J. Cohen and J. Rogers (Eds) Associations and Democracy. London: Verso. 